\title{
The Development of the Russian Environmental Movement in the beginning of XXI Century
}

\author{
Oleg N. Yanitsky* \\ Doctor of Philosophy, Professor, Chief Researcher, the Federal Center of Theoretical and Applied Sociology of \\ the Russian academy of sciences; Chief Researcher of Virtual research-and-development Laboratory the "RNF- \\ 17-45-VP"ISFNandMKof the Kazan University. Address: 117218, Moscow, Russia.
}

\begin{abstract}
*Corresponding Author: Oleg N. Yanitsky, Doctor of Philosophy, Professor, Chief Researcher, the Federal Center of Theoretical and Applied Sociology of the Russian academy of sciences; Chief Researcher of Virtual research-and-development Laboratory the "RNF-17-45-VP"ISFNandMK of the Kazan University. Address: 117218, Moscow, Russia.
\end{abstract}

\begin{abstract}
The article aims at the analysis of Russian environmental movement (hereafter the REM) in the 2000s comparing this evolution with its previous development, on the one hand, and with major trends of similar movements in other parts of the world, on the other. Drawing on the literature on the above movement evolution in other parts of the world and my personal investigations of the development of Russian movement from the 1960s onwards the author came to the following conclusions. First, in spite of authoritarian regime in 1960-90s, the decay of the USSR and rapid economic and social transformations in the 2000s, the REM showed it relative stability and adherence to nature protection values. Second, this relative sustainability has been conditioned by close collaboration of the REM with Russian academic community. Third, the further the more this ties has become more solid. Fourth, it's rather important that some scientists have oscillated between academic community and environmental activity, and some of them left an academic carrier forever while others work as shuttles. Fifth, in spite of growing political restrictions the REM held out against this pressure. Sixth, three qualities were necessary to it: a permanent education (training), a capability to be an experience man and an interdisciplinary approach to analysis, decision-making and action. Seventh, a permanent development and mobility of the REM fits to the non-linear character of world development and quickly changing disposition of geopolitical forces that determine the state of global environment. Eighth, within the REM there are more movable and more stable units and communities. Ninth, integrated world requires mutual understanding and integrated activity. In the end some acute issues of further REM development are considered. Tenth, so-called green cities are still mainly a motto of socially and ecologically safe settlements of a future.
\end{abstract}

Keywords: Academic Community, Education And Training, Experience, Globalization, Environmental Movement, Values, Interdisciplinary Approach, Relative Sustainability, Cities

\section{INTRODUCTION}

Current globalization generates some similar but not always identical processes around the world crossing the nation-state borders and natural-climatic zones. Therefore, current environmental movements are forced to follow these global-local processes. This complex and multisided processes leave an imprint on modern environmental movements including Russian one. In the process of globalization expansion disputable issues have emerged here and there. The other side of the same coin is the development of global stakeholders (like the US, China, India and some others) and their global geopolitical projects. The New Silky Road is the best example. Such cross-borders projects urge national environmental movements including Russian one to join their efforts in the making estimations and prognoses related to environmental and socio-political consequences of such projects. At the same time, the globalization stimulates an activity of large national-international NGOs like the WWF-Russia and the Greenpeace Russia. It doesn't mean that local environmental organization has disappeared. On the contrary, they are forced to restructure their aims and activity that is they are becoming global-local as well. The third overall characteristic of the REM evolution is its past. The core of the REM is still consists of the ideologists and leaders that had shaped in the 1960s. Therefore, it's rather interesting to observe how this core is developing and changing in accordance with entirely new conditions. 


\section{METHOdOLOGY, THEORY AND INSTRUMENTS}

According to many western and Russian researchers, I consider the REM as inseparable part of a civil society that has local-global character as well (Waters, 1995; Castells, 1996; Therborn, 2000). A specificity of this movement is that is based on the union of academics and practitioners that is wellexperienced scientists (Weiner, 1988; 1999). The cornerstone of my methodology and techniques is including observation in its various forms. The best example of such methodology had been given by A. Touraine and his colleagues and titles as the method of a sociological intervention (Touraine et al., 1983).Then, I've used my vast environmental and family archives (semi-structured in-depth interviews, official and human documents, reports, notes in my, itinerary notes which I gathered from early 1970s till now). In particular, this archive contains of about 400 interviews with eco-activists and their counterparts (businessmen, municipal staff, independent and politically-engaged experts, academics, etc.).

As to theoretical underpinnings of this article, the works of U. Beck on risk society (Beck, 1999, 2007, 2015), Z. Bauman on liquid modernity (Bauman, 2001, 2001 a, 2004, 2011), M. Castells on civil society and its grassroots (Castells, 1983), A. Touraine on social activism (Touraine et al., 1983) and J. Urry on global mobility (Urry, 2008, 2011) has been used. Of course, the works on the theory of social movements I use to refer to the works of many sociologists (D. della Porta, B. Klandermans, H. Kriesi, M. Diani and many others).

\subsection{Prehistory}

There were two main sources of the REM shaping: a community of academics and emergent local initiatives (grassroots). It's indicative that the former had been presented not only by biologists but by the politicians, on the one hand, and a variety of academics (biologists, chemists, historians), on the other. For example the outstanding Russian geochemist V.Vernadsky, the author of the Biosphere concept had simultaneously been a municipal activist and then the member of Russian political party of the Constitutional-Democrats. The early 1900s had been the times of the First Russian Revolution (1905-07) that accompanied with the rise of grassroots initiatives of various kinds (education, charity, mutual help, assistance to affected people, etc.). These initiatives were divided in two parts: local and global or/and all-embracing. For example, prof. D. Mendeleev, the author of the 'Periodic System of Elements' was among those who came out against the proposal to use the petroleum as a fuel. Nevertheless, the creation of various kinds of the reserves had been the mainstream of those times.

In the 1920-30s that is in the times of Soviet regime the situation has changed. According to D. Weiner, one of the most serious researchers of the history of Russian environmental activism there were three types of attitudes to the nature and the use of its resources and social sub-groups correspondingly. The first one, the Pastoralists was deeply influenced by German neo-romantisism. The second one, the Ecologists emphasized the Nature's fragility and the dander of ecological collapse. The third one were the Utilitarians based their worldview on current-days economic utility (Weiner, 1988: 229-230). After the WWII the 'Stalin's Plan of the Nature transformation' had been widely announced but had not been realized.

In the 1960s, in spite of existence of state-controlled institutional structure the Russian society of nature protection, a true environmental nature protection organization of the Russian Federation had gradually penetrated into the universities and other higher school organizations. During the decade of the 1960s the Students' Nature Protection Movement (in Russian the 'Druzhina Movement', the DM)had been shaped. Its main features: close collaboration with its university tutors, combination of a desk and field activity and capability to communicate with various strata of the society: municipal administrations, the members of other civil organizations (not only nature protection oriented)and local population including the poachers.

The DM had fulfilled two other very important social functions. On the one hand, it adapted the students from small settlements to urban way of life. On the other hand, it accumulated an experience of man-nature relations of these newcomers. But the key feature of the 'Druzhina Movement' was it network-based principle of organization, initially by means one-to-one communication and then by the IT-networks. The network principle of the REM organization has been absolutely necessary due to a giant size of the USSR territory and a variety of its natural and social peculiarities. 
Even after the USSR collapse and up to now this organizational structure not only still work but serves efficiently as a base for the involvement of new individual participants, the grassroots and for the initiative groups (like Rivers without the Borders) that are dealing with giant transcontinental projects like the New Silky Road. Unfortunately, in comparison with an early 1900s an environmental activism of the scientists and scholars (with some exceptions, see below) gradually reduced. Academics now prefer to be experts or the developers of their own research projects.

Finally, in comparison with early years of Russian perestroika (1986-91s) current grassroots environmental activism of the population reduced as well and its hotbeds are emerging here and there as local protest actions against extra cases like the storage of solid wastes that produce harm to nature and people around them.

\section{Current REM, its Aims, STRuCture AND Modes of ACTION}

There is neither common aim nor united strategy of current EM and the reasons of such situation are clear. First, after a short period of politics of ecological democratization the times of exclusion of the REM from state political arena had begun. It has been realized by many means: by institutional restrictions, organization of state-controlled counter-movements, by introduction of numerous local decrees, instructions and by a wide-spread practice of getting permission for any mass rallies, even when they had absolutely peaceful character. The further the more the state or city authorities aimed to strictly regulate any grassroots activity.

Second, the current environment activism is now very diversified. It may have a form of initiative project, joint research project or a numerous forms of activities united by the issues and risks of a certain territory of a state, group of states or common natural landscape. The key problem is that the tempo-rhythms of environmental or man-made challenges are permanently fastened. Thai is, we are entering in the period of 'regionalization' of the REM aims but these aims may be defined by various factors, territorial, geopolitical and ecological as such or may be conditioned by the prospects of a state or business activity. A set of my pilot research of the issue in question showed that true global environmental problems except global warming are not in the focus of the REM.

Third, as to the Druzhina Movement it's practically disappeared in its previous form. It's indicative that the former the Druzhina members (they are now between 40 and 60 years old) concentrate their efforts on the involvement of the schoolchildren in the REM activity. These children under the assistance of aged activists develop their own nature protection projects. On the other pole, there are aged inhabitants who are trying to defend their neighborhoods and natural surroundings from the invasion of the developers. Nature protection activity in small provincial settlements and villages is usually very low except the case of invasion of tracks with solid and other wastes.

As a result the international platforms like the Socio-Ecological Union-International or the Research gate have emerged. Their aim is to inform Russian and world environmental community about current trends not only in environmental spheres of science and practice but in many other neighboring spheres of social life as well. Interdisciplinary research projects are the most highly valued.

Organizational structure of the REM is usually reflects its project-oriented socio-functional structure and resulted in getting state or business financial aid by particular ecological groups. But there are the exceptions. Such projects may be initiated top-down as a result of a monitoring of current situation on a particular territory or of the emergence of various critical conditions (natural and man-made disasters). In 1960-90s, the structure of the REM had been based on the networks of the Druzhina Movement and the Socio-Ecological Union. Of course, international projects like the 'Cities of Europe: The Public Participation in the Shaping of Urban Environment', the 'Taiga Rescue Network' and numerous grassroots initiatives had been developed. Anyhow, the REM became tempered in the struggle with its opponents and participating in the resolving of ecological conflicts.

Although, the further Russian capitalism had been developing the more unprofessional grassroots had declined and replaced by more professional groups guided by experienced leaders capable to make many deeds simultaneously (to make fundraising, to establish contacts with sister groups, etc.). Two qualities - an environmental knowledge and accumulated experience in many fields - allowed to the REM to survive in the run of financial crises in the 1990s-2000s years and later on to overcome political and legislative restrictions imposed on the environmental NGOs. 
As to a mode of action, it's usually defined by a situation in situ and the disposition of forces involved, or on the contrary, by an ideology and action plan for its implementation. Therefore, the REM activity is varied from the analysis of state's or the transnational's plans of further development of a particular territory, letters and appeals to the municipal and state authorities till long-term struggle of civil society organizations for nature protection, against changes in environmental legislation, the struggle for human rights and freedoms in ecological sphere, etc.

It should be noted that initial political division on anarchists, conservationists, social democrats and technocrats peculiar to the 1990s had been gradually levelled in the course of the above struggle. It may seem a bit paradoxical but under globalization the REM is appeared as more territoriallysounded. But the very territory has usually been defined as a space of current or future activity of a particular state or the alliance of the states coupled with global stake holders. The globalization stimulates an activity of large national-international NGOs like the WWF-Russia and the Greenpeace Russia. An international activity of various grassroots organizations stimulated by the China's the New Silky Road Project is the best example of such national-international initiative. Besides, it shows that globalization process may have not only world-wide character but a form of a linear 'bridge' between the China and the European Union, the two great civilizations of the world (Yanitsky, 2018). It means that a certain global idea may be a driving force of transnational globalizing processes of Russian environmentalists.

As such, a certain space cannot be definitely outlined under globalizing world. Therefore, an activity of particular environmental group has an indefinite i.e. uncertain aims and character. In other words, a mobile world (a liquid world, according to Z. Bauman) conditions a mobile character of the above pro et contra groups.

In this respect the initiative of Russian grassroots group 'Help to the River!' is very interesting. Environmental activists and ordinary peoples who lived along the coasts of the Volga river had organized the environmental movement aimed at to clean its coasts from plastics and other wastes, to plant trees, etc. This initiative is conducted in the frames of the Youth European water parliament and backed by many local nature protection civil organizations of the RF. Having non-political character, this initiative meats an urgent need of thousands people for living in a safe and clean environment. If this action will be successful the Youth Volga river parliament (as a public organization) will be established (Volga river chain, 2018).

\section{A 'Greencity': An Ideal Model of a Future Society or actual Program of RENOVATION?}

In this case we observe an interesting situation. On the one hand, the modeling of the 'green cities' stood always apart from the mainstream of the REM both institutionally and empirically. Such modeling has always been tightly connected with philosophical foundations of humanism and human wellbeing. More than that, the ideal cities models sometimes had been considered as a 'repetition' on the ground of eternal principles of the universe structure.

On the other hand, the modeling of the 'green cities' represents an attempts to resolve the most urgent issues of rapidly developing capitalist society. In the former case the constructors of the 'green cities' had been philosophers like T. Campanella and T. Moor, high-ranked state officials and architects. A key idea of each model was a creation of a city model of a just social order and common wellbeing. In the latter case it was going on about of already existing or projecting cities which have to meet modern requirements, economic, social cultural and ecological ones. It means that the heading the 'greens' used only as a symbol of a better future what is usually remains on paper. In both cases we are dealing with rather simplified models that doesn't take into account a very complicated (i.e. localglobal, interdisciplinary), mobile and uncertain reality.

I don't neglect a necessity of the development of such models but if they would be realized they undergo radical transformations. If our world has become liquid and mobile the 'green cities' models have to fit to these fundamental features of world dynamics. It had been clearly showed by J. Forrester in his two books, the 'Urban dynamics' and the 'World dynamics' (Forrester, 1969, 1971). Whatever model of the 'Green Cities' cannot be realized without mutual trust and understanding in a given society. A global sociology is urgently needed in revitalization of social prognostics but now as a multidisciplinary science-practice discipline. 
One more principled point should be mentioned. In a market economy and growing global tension a contradiction between the developers and urban planners are sharpening. The developers as direct representatives and participants of market economy are interested in getting a maximum profit whereas the creators of the 'green' or other ideal cities are mainly interested in public effect of their projects and their own publicity or in a 'demonstrative effect', as it had been called by world-known anthropologist B. Malinowsky.

In essence, future cities will be very complex socio biotechnical systems (the SBT-systems) subjected to permanent transformations *(Yanitsky, 2016). There are many confirmation of this thesis which coming from the various parts of the world and the RF in particular. The reasons of such activity may be various. In one cases it's a result of worsening environmental conditions in particular cities and small settlements in various part of the country. In other cases local residents and grassroots activists are bothered by the global projects like the New Silky Road which realization undoubtedly changes an overall structural-functional organization of these settlements and inner and surrounding natural landscape around them.

There is one more global-local risk. The matter is that interdisciplinary teams from the countries that may be potentially threatening by the above project are now analyzing not the New Silky Road project as such and its possible consequences but only a discourse related to this project. In turn, such discourse is based on the experts' opinions and not on the field researches. In sum, we have the discourse-based-on-discourse that some of my western colleagues named as poststructuralist analysis. It means that the actual near and far-reaching environmental and other risks are not analyzed. But local residents as well as the developers well-understand that all regional and may be global SBTsystem will changed.

\section{Shaping OF A NeW TyPe OF ENVIRONMENTAL ACTIVIST}

As it had been mentioned, an 'ideal' model of such person combines three qualities: empiricallygained environmental knowledge, a capability to think and act in interdisciplinary manner and a capability to communicate with various social and professional groups. More than that, my long-term studies of science-practice interactions showed that new type of knowledge production has emerged: joint scientific-public researches. There are at least five main forms of evolution of its producers and carriers.

The first one, the 'top-down' one which I'd called a neutral is presented by an outside scientists occasionally invited by an eco NGO as an experts. Working in accordance with their professional standards and relying on their previous experience, the neutrals write their conclusions on the language accepted in a given branch of science. The second one - an aware or understanding includes scientists and scholars whose regular collaboration with the NGOs helps them to gain better understanding a particular subject matter. The third type - an involved - is a scientist or scholar who began to share the values of the NGOs and to collaborate with them. The fourth type - a partner - is represented by a scientist who is actually becoming the NGOs' activist. The fifth type - fully integrated - is represented by the researchers who have left their job at the research institute or at the higher school and becomes a member of a grassroots, the NGOs or even creates its own civil society organization. It's rather important that for such shift is not only a will and full change of way of life is required but the fully integrated scientist began to produce a new type of knowledge. This integrated knowledge is created, reviewed and disseminated in the process of dialogue between science, culture, administrative agencies and local population (Yanitsky, 2005: 88-91).

The mediating kind of environmental knowledge production is specific. It has been produced by the activist who oscillated between the state and civil environmental organizations. Several reasons had conditioned such instability. The first kind of this type had emerged when many Druzhina's members graduating from the universities have been forced to look for permanent job. In other cases these activists were forced to combine the work in an office and in an ecoNGO. It gave new knowledge and experience but not a daily stability. The third one, and as seems to me the most important, when these in-between activists were felt on themselves the breath of globalization and its impact on global environment.

But to my mind, a young generation of Russian environmental activists is differed from the abovementioned. These activists are well-educated, mainly in the US and the EU universities, have waste contacts in various spheres of Russian society and abroad, acquired a good deal of experience in 
research, organizational and field work, etc. And the most important that this new generation of Russian environmentalists are mostly the insiders in relation to the issues in that they are involved. It doesn't mean that previous generations were not involved. But it's a great difference if environmental activist is involved in local issues that are measured by billions of square kilometers or even has a global scale. A specificity of global perception and thinking requires an in-depth multidisciplinary research and therefore this problem is beyond the frames of this article.

At the same time one can observe the shift of focus of adult and experienced Russian environmentalists on children and teenagers. Keeping in mind the coming of the Fourth industrial revolution and total robotization (Schwab, 2016; Collyer, 2018), these activists see that an early environmental education and training is the only one way to make the next generation much more environmentally-sensitive and resistant in relation the attempts to replace natural landscape by technologically-constructed one. It's rather important that schoolchildren are carrying out environmental research together with their adult teachers and eco-activists.

\section{THE CAPITALISM IS SOMEWHERE FAR OR NEAR?}

The majority of Russian people are still concerned with their current needs: work, food supply, children, old or weak relatives, etc. Therefore, the rank-and-file people see market economy is something like unstable weather, it's unpleasant but unavoidable. These people immediately react only on critical situations like the disasters, forest fires or floods. The burst of public protests of small town residents around Moscow against waste grounds is a typical example. It's a very indicative case because Russian capitalism had been so quickly and forcefully introduces that there were neither time nor resources to think about the wastes and their environmental consequences. The ideology of consumer society only provoked the growth of wastes and construction of waste grounds. A selection of the garbage is not usually used in the large cities that are the main producers of it. It means that the large cities are existed at the expense of their extensive natural periphery including small towns and villages.

In spite of gradually restricting legislation local eco-NGOs continue their struggle against ecologically-threatening events and already existing constructions. As Russian history shows, these NGOs appeared very resistant to any outside pressure, be it a state, municipal or business organization. Besides, in such critical cases (accidents) the role of journalists is rather important because the growth of environmental journalism is a permanent source of environmentally-sound information. In a manner, this means the revitalization of scientific publicism that had been well developed in the Soviet times and totally destroyed in the run of the perestroika years. Besides, these journalists show to activists long-term transformations in peoples' behavior generated by a peaceful and military activity.

\section{The GrowTH OF THE ECO-SETTLEMENTS}

These settlements seem to me as utopian ones because sooner or later their inhabitants have to be included into urban life (children's education, higher education, medical care, etc.). Nevertheless, such settlements exist not only in Russia but in some European countries. In the 1991 the Global eco village Network has been established. As one of well-known leaders of Russian environmental movement S. Zabelin stated, there are about 450 Russian eco-settlements in his personal data-base. According to his classification, there are a set of main types of these settlements, patrimonial settlements, profile, social and eco-settlements as such. All eco-settlements are emerging on the base of shared values, common labor and on the ability to overcome emerging social conflicts (Sablin, 2018).

The patrimonial settlements (more exactly the estates) are usually situated in the forests. A core of such estates is usually big families that conduct a common natural economy involving in it teenagers. It's a typically Russian rural-urban mode of living. Therefore, its inhabitants tried to escape to call their extended community as the eco-settlements. The profile settlements are usually established by the IT-or other professionals. In one way or another, these settlements represent a 'cage' of the profession of their organizers. To my mind, it is the most 'light' variant of eco-settlements very close to summer-house of an upper middle-class. The social settlements are organized and maintained by the families with adopted children usually taken from special houses for such children-without- 
parents. Again from my viewpoint only, it is the settlement with the most humanistic aims. The problem here is that a structure and functions of such settlements have to be changed. Finally, the ecosettlements as such cannot be well-defined. The only one aim common to all of them is that all their inhabitants tried to protect nature in one way or another. Nevertheless, there are such eco-settlements whose inhabitants bury the wastes in the near forest. I'd like to add to this list one more type of ecosettlement which I called a mobilization one. I mean the attempt to build the 'Cedar city' (Kedrograd) to save this very valuable type of forests from their destruction. This real case happened in the year of 1960 is well-described in the book titled 'Murmur taiga, Murmur!'(Chivilikchin, 1960). The time had changed but the country is still needed in bold-spirit, well-educated, experienced, and capable pioneers to maintain a multidisciplinary dialogue.

\section{WHAT FORMS OF ENVIRONMENTAL ACTIVISM ARE STILL UNDERDEVELOPED?}

The further the more rank-and-file people both in cities and outside them began to realize that the capitalist mode of production in its current state is inseparable from extra-payments in the form of the production of packing materials (wrappings) and various forms of advertising of goods and services.

First, it is a lack of so-called critical activism that is the activism under critical conditions. The matter is that existing services of environmental control are very weak and often corrupted. Second, the troops of the State Ministry of Accidents have very restricted list of their functions. They save peoples and buildings from the forest-fires and floods but are not obliged to protect the environment and to bother about the further faith of affected people. Third, in comparison of civic defense forces and instruments existed during and after the WWII the existing system of civic defense is not obliged to save ordinary people. Fourth, the NGOs and other civic organizations have no rights and resources to protect people and their immediate environment in the case of natural and man-made disasters. Fifth, the very civic organizations being deeply involved in their current deeds have no time, equipment and resources to even think about possible critical situations. Nevertheless, if natural or man-made accident is happened civic activists are working hand by hand with the professional rescuers. Sixth, Some of Russian environmentalists show exceptional 'universalism' in their look on a particular issue i.e. multidisciplinary approach in the face of continental or global projects developed by the US, the EU, China and other countries. Seventh, some of Russian environmentalists show exceptional 'universalism' in their look on a particular issue i.e. multidisciplinary approach in the face of continental or global projects developed by some global stakeholders. Eighth and the most important, recently environmental activism have to embrace all spheres of economic, social and cultural activity.

\section{CONCLuSion}

In spite of a 'capitalist revolution' in Russia the REM has survived and demonstrated its relative sustainability. But global world is rapidly changing and the REM is forced to follow these transformations. The REM never has neither financial nor intellectual resources to outstrip these transformations and therefore to predict negative environmental consequences of myriad human activities. Such consequences may by predicted on local scale only. Therefore, to my mind, a main role of Russian eco-activism is to analyze overt intentions of national and global stakeholders and their geopolitical actions. It means that Russian eco-activists are needed in modern means of the monitoring and observation.

The political differentiation of Russian environmentalists existed in the mid-1990s has disappeared in the face of global environmental threats or man-made accidents. This differentiation has been gradually replaced by two types of the REM organizations: large internationally-sound organizations like the WWF-Russia and the Greenpeace-Russia and some miner organizations and even informal groups like the Rivers without Borders that nevertheless potentially may has a great impact on global and sub-continental environmental politics.

These activists are working in much more restricted circumstances than their predecessors in the beginning of the XX century (there is no such local self-government as it had been the zemstvo in the past, and much more strict legislation related to the grassroots activity). But the activists are supported by world network of sister organizations.

There is a decline of the role of science and scientific institutions in environmental research and a growing strength of civic organizations but still not well-scientifically sound. And accordingly the 
transformation of scientists and scholars into environmental activists is continued. The other side of the same coin is that the science as a social institution (with few exceptions) had been replaced by socially-constructed media-news. Nevertheless, a lot of relatively young professionals (35-45 years old) in environmental issues are efficiently combines their researches with civil activism.

The other distinguishing feature of the REM is the emergence and maturing of civic-professional organizations. It's a new social institution that is both profitable to many state organizations and to ecological NGOs themselves. There is a wide-range practice when an environmental specialist permanently working in state organization and simultaneously participating in an eco-NGO as an independent expert.

Funding: This article is written with the support of the Russian Fundamental Research Fund under grant 'Russian megacities in the context of new Social and Environmental Challenges: Building Complex Interdisciplinary Model of and Assessment of 'Green' cities and Strategies for their Development in Russia' the project no 17-78-20106.

\section{REFERENCES}

[1] ChivilikchinVl. 1960.Murmur Taiga, Murmur! Moscow: Publishing House 'Pravda' (in Russ.).

[2] Bauman Z. 2001.On Glocalization: Or Globalization for some, localization for some others, in: Bauman Z. The Bauman reader. Malden, MA: Blackwell Publishers Inc.: 298-311.

[3] Bauman Z. 2001a.The Individualized Society. London: Polity.

[4] Bauman Z. 2004. Wasted Lives. Modernity and its Outcasts. Cambridge, UK: Polity Press.

[5] Bauman Z. 2011.44 Letters from Liquid Modern World. Cambridge: Polity Press.

[6] Beck U. 1999.World Risk Society. Malden, MA: Polity Press.

[7] Beck U. 2007.Risk Society. Cosmopolitan Version. Cambridge: Polity Press.

[8] Beck U. 2015. Emancipatory Catastrophism: What does it mean to Climate Change and Risk Society? Current Sociology, 63 (1): 75-88.

[9] Castells M. 1983. The City and the Grassroots. A Cross-Cultural Theory of Urban Social Movements. London: Edward Arnold, Ltd.

[10] Collyer F. 2018. Global Patterns in the Publishing of Academic Knowledge: Global North, Global South. Current Sociology, Vol 66 (1): 56-73. DOI: 10.1177/0011392116680020

[11] Deelstra T. and Yanitsky O., eds. 1991.Cities of Europe: The Public's Role in Shaping the Urban Environment. Moscow: Mezhdunarudnye Otnosheniya.

[12] Forrester J.W. 1969. Urban Dynamics. London: The M.I.T. Press.

[13] Forrester J.W. 1971. World Dynamics. Cambridge: Wright-Allen Press.

[14] SablinR. 2018. Romantics of the XXI century are going to eco-settlements http://plus.one.ru/blog/ comunity/ romantiki-21-veka-edut-v-ecoposeleniya

[15] Schwab K. 2016. The Fourth Industrial Revolution. Geneva: World Economic Forum.

[16] Therborn J. 2000. Three concepts of globalization. International Sociology, Vo. 15 (2), p. 180-196.

[17] Touraine A., Dubet F., Hegedus Z., Wieviorka M. 1983.Anti-nuclear Protest.The Opposition to Nuclear Energy in France. Cambridge: Cambridge University Press.

[18] Urry J. 2008.Mobilities. Cambridge: Polity Press.

[19] Urry J. 2011.Climate Change and Society. Cambridge: Polity Press.

[20] Volga River Chain. 2018. Accessible at: https://docviewer.yandex.ru/view/81646754/

[21] Wallerstein I. 1994. World-system Analysis, in: The Polity Reader in Social Theory. Cambridge, UK: Polity Press: 276-286.

[22] Waters M. 1995.Globalization.Lnd. \& N.Y.: Routledge.

[23] Weiner D. 1988.Models of Nature: Ecology, Conservation, and Cultural Revolution in Soviet Russia, Bloomington, Indiana University Press.

[24] Weiner D. 1999.A Little Corner of Freedom. Russian Nature Protection from Stalin to Gorbachev, Berkeley, Los Angeles, University of California Press.

[25] Yanitsky O. 2005. Dialogue between Science and Society. Social Sciences. A Quarterly Journal of the Russian Academy of Sciences, Vol. 36, No 2: 78-90.

[26] Yanitsky O. 2018. Globalization and a New Silky Road Project. Advances in Social Sciences Research Journal. Vol.5, No.4. Pp. 13-23. URL: http://scholarpublishing.org/index.php/ASSRJ/article/view/4354 
[27] Yanitsky O. 2016.Sotsiobiotechnical systems: A new Approach to Man-Nature Interactions, in: On Globalization and its Environmental Consequences. The Yanitsky Reader II, pp. 123-135. Available at: http://www.isras.ru/index.php?page_id=1198\&id=4603

Citation: Oleg N. Yanitsky. “ The Development of the Russian Environmental Movement in the beginning of XXI Century". International Journal of Humanities Social Sciences and Education (IJHSSE), vol 5, no. 6, 2018, pp. 23-31. doi: http://dx.doi.org/10.20431/2349-0381.0506004.

Copyright: (C) 2018 Authors. This is an open-access article distributed under the terms of the Creative Commons Attribution License, which permits unrestricted use, distribution, and reproduction in any medium, provided the original author and source are credited. 